\title{
Effect of milk bactofugation on the counts and diversity of thermoduric bacteria
}

\author{
J. C. Ribeiro-Júnior, ${ }^{*} \odot$ R. Tamanini, $\odot$ A. A. Alfieri, $\odot$ and V. Beloti \\ National Institute of Science and Technology for the Dairy Production Chain (INCT - Leite), Federal University of Tocantins, Araguaína, Tocantins, \\ Brazil 77804-970
}

\begin{abstract}
The objective of this work was to determine the effect of milk bactofugation on the counts and microbial diversity of mesophilic (MT), psychrotrophic (PT), and thermophilic (TT) thermoduric bacteria and its potential as a technological method to remove spoilage microorganisms resistant to pasteurization. Different batches of raw milk from 69 dairy farms divided into sets in 3 bulk tanks (A, B, C) were evaluated at different times during the technological process. As the raw milk was preheated $\left(\sim 55^{\circ} \mathrm{C}\right)$ immediately before bactofugation $(10,000 \times g)$, the effect of bactofugation was estimated by comparing the counts in raw, preheated, and bactofuged milk. This centrifugation was sufficient to reduce the isolation of $88 \%$ of the MT in preheated milk. For PT, it was possible to verify a reduction of $72.5 \%$ in batch $\mathrm{C}$. The TT were not recovered at higher detection limits $(<5 \mathrm{cfu} / \mathrm{mL})$. For diversity, 310 isolates were identified using a molecular approach; 15 species of contaminating thermoduric bacteria were identified from raw and preheated milk, and only 6 species were recovered in bactofuged milk. Only MT were recovered from the bactofuged milk, mainly the species Lysinibacillus fusiformis (61.7\%) and Bacillus licheniformis $(12.3 \%)$. Both species are known to be endosporeforming psychrotrophs and have proteolytic or lipolytic activity. The bactofugation of raw milk reduced the number of isolates of B. licheniformis, Bacillus toyonensis, Micrococcus aloeverae, and Aestuariimicrobium kwangyangense by $33,43,86$, and $92 \%$, respectively, and reduced the isolates of Macrococcus caseolyticus, Lysinibacillus varians, Carnobacterium divergens, Microbacterium hominis, Kocuria indica, Micrococcus yunnanensis, Gordonia paraffinivorans, Bacillus invictae, and Kocuria kristinae to undetectable levels. The results of this study indicate that bactofugation can be
\end{abstract}

\footnotetext{
Received March 25, 2020

Accepted June 3, 2020.

*Corresponding author: ribeirojuniorjc@gmail.com or jcribeiro@uft .edu.br
}

applied by the dairy industry to reduce pasteurizationresistant microorganisms in combination with prophylactic measures to prevent the contamination of raw milk by spores and vegetative forms of bacteria.

Key words: bactofugation, endospore-forming bacteria, high centrifugation, Lysinibacillus fusiformis

\section{INTRODUCTION}

Thermoduric bacteria are microorganisms capable of resisting pasteurization (Huck et al., 2007). Due to the proteolytic or lipolytic activity of these bacteria, they are often responsible for reducing the shelf life of pasteurized milk (Durak et al., 2006; Ribeiro Júnior et al., 2018a). Reducing the microbiological contamination of raw milk is essential to extend the shelf life of pasteurized milk (Murphy et al., 2016; Ribeiro Júnior et al., 2019a).

However, endospore-forming microorganisms, for example, which are difficult to control during milk production, can compromise the shelf life of pasteurized milk by spoilage activity of vegetative forms after spore germination (Huck et al., 2007) or promote undesired changes to cheese production (Oliveira et al., 2016). The vegetative forms of endospore-forming bacteria can be thermoduric (Ribeiro Júnior et al., 2018a) as well as other bacteria that do not form spores (Delgado et al., 2013; Ribeiro Júnior et al., 2018a).

Thus, the use of methods to reduce the number of bacterial endospore-forming agents in raw milk can be used to extend the shelf life of pasteurized milk and reduce the technological problems of dairy products produced with pasteurized milk. The study by Khanal et al. (2014), for example, reports that the ultrasonication of milk can eliminate the vegetative forms of the thermoduric bacteria of the genus Bacillus.

One of these methods, bactofugation, is the use of a high-speed centrifuge specifically designed to remove bacterial spores from milk at high temperatures (Farkye, 2004). The bactofuge centrifuges the milk at approximately $9,000 \times g$ for less than $1 \mathrm{~s}$ at 55 to $60^{\circ} \mathrm{C}$ (Gésan-Guiziou, 2010), thereby removing the concen- 
trated bacterial pellet that contains spores (Stack and Sillen, 1998).

Many studies have evaluated the use of this technology only to reduce bacterial spores and have reported its efficiency in reducing gram-negative bacteria, mainly for cheese production (Kosikowski and Fox, 1968; Torres-Anjel and Hedrick 1971; Faccia et al., 2013), which has limited its use on a large scale due to its applicability in only a few situations. Little is known about if this method is able to remove vegetative forms of spoilage microorganisms of raw milk that remain after pasteurization. Our objective, therefore, was to verify the effect of bactofugation of raw milk on the counts and microbial diversity of mesophilic (MT), psychrotrophic (PT), and thermophilic (TT) thermoduric bacteria.

\section{MATERIALS AND METHODS}

Three different batches of raw milk (A, B, C) were evaluated immediately before processing by a dairy company in the state of São Paulo, Brazil. Each batch was stored in an individual bulk tank. Batch A was composed of approximately 15,000 L (from 12 farms), B had 20,000 L (26 farms), and C had 11,000 L (31 small dairy farms). Thus, milk from 69 different dairy farms was evaluated in 3 sets. As the bactofugation process is carried out after milk heating $\left(\sim 55^{\circ} \mathrm{C}\right)$, the batches were evaluated in 3 stages during processing: raw, preheated (the condition immediately before bactofugation), and bactofuged milk.

Refrigerated raw milk was collected from the bulk tanks. The remaining samples from the batch were collected after the installation and asepsis of sanitary taps in the pipe in the entrance (preheated) and exit of the bactofuge that were hermetically closed. Aseptic sampling $(\sim 500 \mathrm{~mL})$ of each batch was performed continuously during processing to ensure it was representative of the entire batch. The bactofuge installed in the cheese factory (Padroniza Indústria Brasileira de Pasteurizadores Ltda., Bauru, São Paulo, Brazil) had a force of $10,000 \times g$ with a continuous flow of $10,000 \mathrm{~L} / \mathrm{h}$. The concentrated bactofugate was discarded (less than
$1 \%$ ). The milk samples were sent under refrigeration to the Laboratory of Inspection of Animal Products of the National Institute of Science and Technology for the Milk Production Chain, headquartered at the State University of Londrina in Paraná state (Brazil). The interval between collection and the microbiological analyses did not exceed $4 \mathrm{~h}$.

Thermoduric bacteria were enumerated after heating milk $(5 \mathrm{~mL})$ to a temperature that simulates pasteurization $\left(62.8 \pm 0.5^{\circ} \mathrm{C}\right.$ for $\left.30 \mathrm{~min}\right)$ followed by immediate refrigeration at $10^{\circ} \mathrm{C}$, keeping with the findings obtained by Frank and Yousef (2004). After treatment, serial dilutions of the samples were performed up to $10^{-3}$ in sterile peptone $(0.001 \%)$ saline $(0.85 \%)$ solution, and duplicates were surface plated $(0.1 \mathrm{~mL})$ on plate count agar (Oxoid, Basingstoke, UK). Plates were incubated at $35 \pm 1^{\circ} \mathrm{C}$ for $48 \mathrm{~h}$ for $\mathrm{MT}, 7 \pm 1^{\circ} \mathrm{C}$ for $10 \mathrm{~d}$ for PT, and $55 \pm 1^{\circ} \mathrm{C}$ for $48 \mathrm{~h}$ for TT. The results of the counts were submitted to nonparametric statistical analyses by $\chi 2$ test in SAS software (v. 9.0; SAS Institute Inc., Cary, NC).

All colonies from one of the duplicate plates were recovered in brain heart infusion broth (Acumedia, Baltimore, MD), purified on plate count agar, and subjected to DNA extraction according to the protocol of Ribeiro Júnior et al. (2016). All extracts were subjected to amplification of the internal transcribed spacer (ITS) region of 16-23S rRNA using the primers and conditions as described in Table 1 . We performed PCR with approximately $50 \mathrm{ng}$ of DNA template, 100 $\mathrm{n} M$ each dNTP, $5 \mu \mathrm{L}$ of $10 \times$ buffer, $75 \mathrm{mmol} / \mathrm{L} \mathrm{MgCl}_{2}$, $20 \mathrm{pmol} / \mathrm{L}$ of each primer, and $2.5 \mathrm{U}$ of Platinum Taq DNA polymerase (Invitrogen, Carlsbad, CA).

The amplicons of the ITS region were subjected to restriction with $2 \mathrm{U}$ of the enzyme HhaI (Invitrogen) using the reaction protocol described by the manufacturer The amplified DNA and enzyme mixtures were incubated for $1 \mathrm{~h}$ at $37^{\circ} \mathrm{C}$ in a thermocycler.

The amplification profiles of the ITS regions of each isolate, together with the $H h a \mathrm{I}$ restriction product, were used as genomic variables to construct a dendrogram of phylogenetic similarity (Ranjard et al., 2001) using Bionumerics version 1.50 software (Applied Mathemat-

Table 1. Primers and PCR cycling conditions

\begin{tabular}{|c|c|c|c|c|}
\hline Gene & Primers $\left(5^{\prime}-3^{\prime}\right)$ & $\begin{array}{l}\text { Size } \\
(\mathrm{pb})\end{array}$ & PCR cycling conditions & Reference \\
\hline ITS & CCGGGTTTCCCCATTCGG & &  & \multirow{2}{*}{$\begin{array}{l}\text { Normand et al } \\
(1996) \\
\text { Edwards et al. } \\
(1989) \\
\text { Osborne et al. } \\
(2005)\end{array}$} \\
\hline $16 \mathrm{~S}$ rRNA & $\begin{array}{l}\text { GAGTTTGATCMTGGCTCAG } \\
\text { GGYTACCTTGTTACGACTT }\end{array}$ & 1,465 & $\begin{array}{l}94^{\circ} \mathrm{C} 5 \min \\
35 \times\left(94^{\circ} 1 \mathrm{~min}, 58^{\circ} \mathrm{C} 1 \mathrm{~min}, 72^{\circ} \mathrm{C} 1 \mathrm{~min}\right) \\
72^{\circ} \mathrm{C} 10 \mathrm{~min}\end{array}$ & \\
\hline
\end{tabular}


ics, Kortrijk, Belgium). The similarity matrix Dice coefficient (Dice, 1945) and the unweighted pair group mean algorithm (Sneath and Sokal, 1973) were used. To determine clusters, a minimum of $60 \%$ phylogenetic similarity was used.

A random representative sample from each cluster was selected for partial amplification of the $16 \mathrm{~S}$ rRNA gene using the primers and conditions described in Table 1. The products of this PCR were purified (PureLink Genomic DNA Purification Kit, Invitrogen) and quantified (Qubit dsDNA HS Assay Kit, Invitrogen) for DNA sequencing using the Sanger method (ABI 3500 Genetic Analyzer, Applied Biosystems, Foster City, CA) that was completed in both directions.

The quality of the sequences was evaluated by the software BioEdit version 7.2.5 (Hall, 1999) and the consensus sequences were generated by CAP 3 (Huang and Madan, 1999). These sequences were individually aligned using Clustal $\mathrm{W}$ and the representative sequences of each genus available in the Ribosomal Database Project (https://rdp.cme.msu.edu/), and genetic similarity was analyzed via the neighbor-joining method and the Tamura-Nei model using 1,000 bootstrap replications in MEGA X software (Kumar et al., 2018).

\section{RESULTS AND DISCUSSION}

The MT, PT, and TT counts of the 3 milk batches at the 3 processing times are described in Table 2 . The counts of mesophilic thermoduric bacteria were determined to be predominant over the others. It was possible to observe that bactofugation associated with preheating reduced the mean counts of MT by $96 \%(P$ $<0.05)$ in relation to raw milk. In relation to preheated milk, bactofugation was able to reduce the MT counts by $88 \%(P<0.05)$.

This significant reduction found in MT was not observed when compared with $\mathrm{PT}$, which reached $52 \%$ (Table 2). The low effect of the bactofugation on the PT may be the result of the low presence of these microorganisms in the samples. In addition, psychrotolerant sporeformers are typically present in raw milk in low levels (Masiello et al., 2017). As seen in Table 2 in batch $\mathrm{B}$, no PT isolate was observed in milk immediately after preheating, or in batches A and B after bactofugation. Likewise, it was not possible to verify the effect of bactofugation on TT due to the nonrecovery of isolates in the count plates $(<5 \mathrm{cfu} / \mathrm{mL})$ of raw milk from batches $\mathrm{B}$ and $\mathrm{C}$ and from the preheating of batch A.

If the microbiota of this sample unit had higher counts of PT and TT, it would be possible to verify the potential of bactofugation with more robust results.

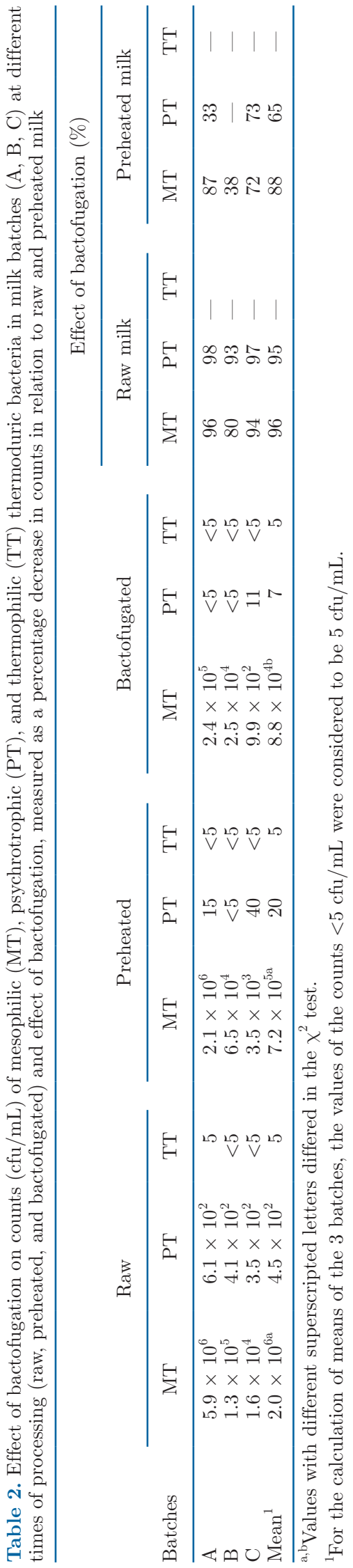


However, considering the results of the batches alone, in batch $\mathrm{C}$, which had counts of PT both after preheating $(40 \mathrm{cfu} / \mathrm{mL})$ and after bactofugation $(11 \mathrm{cfu} / \mathrm{mL})$, a reduction of $72.5 \%$ was observed.

In a previous report, we already demonstrated that bactofugation has a significant effect on counts and on the diversity of psychrotrophs (Ribeiro Júnior et al., 2019b), reducing this microbiota by $89.66 \%$. Psychrotrophs and thermodurics are the agents mainly responsible for the spoilage of raw and pasteurized milk, respectively (Mane and Gandhi, 2011; Ribeiro Júnior et al., 2018a). Avoiding contamination of raw milk by these microorganisms is essential to increase the technological potential of processed milk (Murphy et al., 2016). The use of bactofugation in this context can help to significantly reduce the contamination of milk by these microorganisms with spoilage potential, preserving the quality and integrity of the milk constituents.

Faccia et al. (2013) verified a reduction of Enterobacteriaceae and Pseudomonas in Mozzarella cheeses produced with bactofugated milk, and Kosikowski and Fox (1968) demonstrated the reduction of coliforms by bactofugation in milk intended for cheese production. This can be explained by the low thermal resistance of gram-negative microorganisms to the preheating process. Torres-Anjel and Hedrick (1971) demonstrated that the bactofugation of milk can reduce spore counts 98 to $>99 \%$, a result similar to the $96 \%$ reduction in MT verified by the present study.

From the plates used in the counts, 310 thermoduric isolates were recovered. We isolated $229 \mathrm{MT}, \mathrm{PT}$, and TT from the raw and preheated milk samples according to the distribution shown in Table 3. All of the thermoduric microorganisms isolated from the bactofuged milk (81) were mesophilic, and the distribution of these isolates by batch is shown in Table 4 .

Although batch $\mathrm{C}$ had colonies of PT on the plates after bactofugation, which could be used to identify this microbiota, no isolates were recovered in the subsequent steps. It was also not possible to recover PT isolates (batches A and B) or TT isolates from bactofuged milk, which supports the results of counts $<5$ $\mathrm{cfu} / \mathrm{mL}$ observed in Table 2. All TT were isolated from raw milk in batch $\mathrm{A}$.

Table 3. Identification by cluster of genetic similarity of mesophilic (MT), psychrotrophic (PT), and thermophilic (TT) thermoduric isolates from batches of raw and subsequently preheated milk before bactofugation

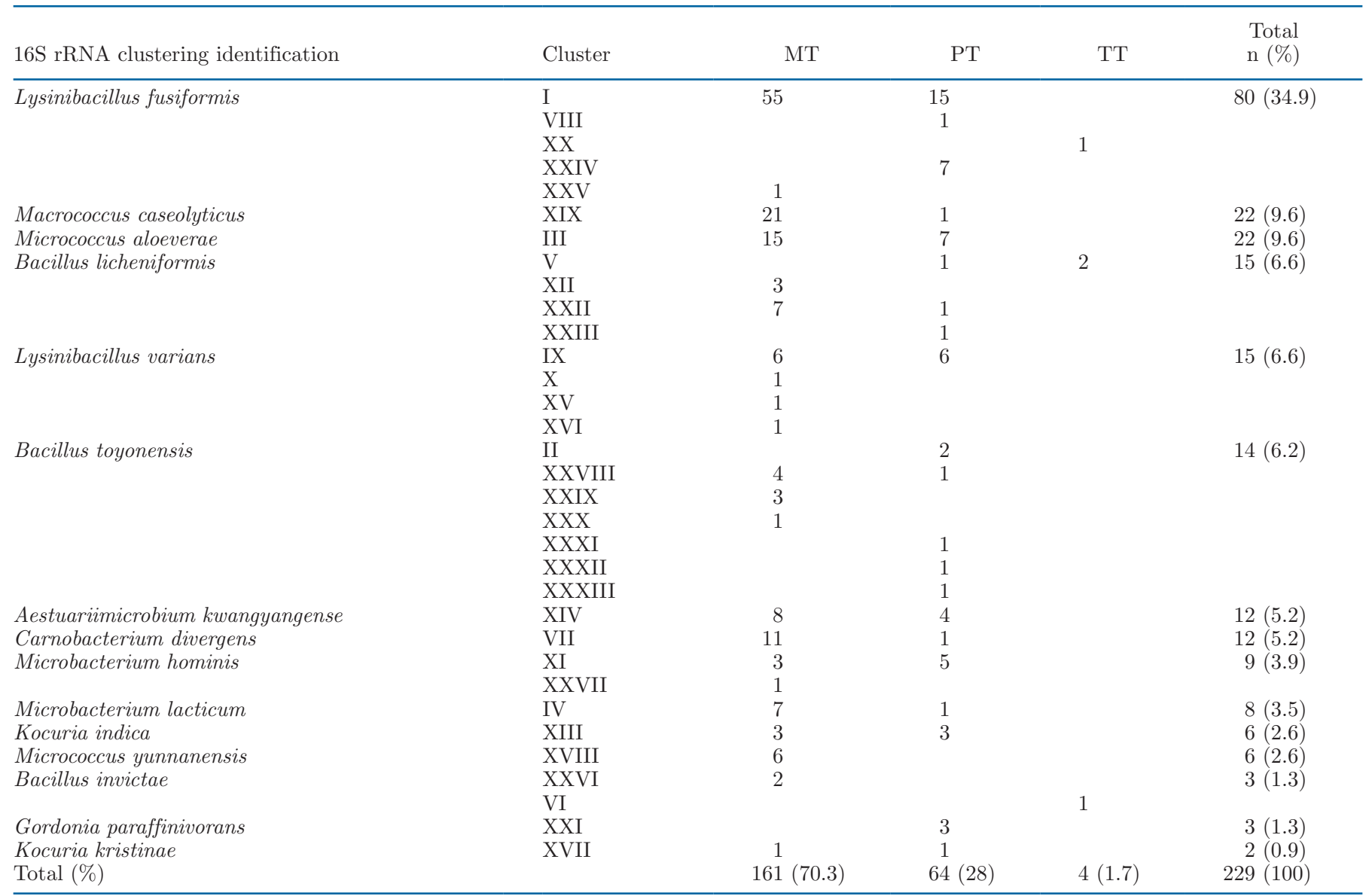


Regarding microbial diversity, using the genetic variables of the amplification profile of the ITS region and its restriction with the HhaI enzyme, 33 (I-XXXIII) clusters of genetic similarity were observed for the 229 isolates of MT, PT, and TT from raw milk and preheated milk (Figure 1), and 12 (I-XII) clusters for the MT isolates from the samples of bactofuged milk (81; Figure 2). The identification of isolates by cluster is shown in Tables 3 and 4 . Fifteen species of thermoduric contaminants from raw and preheated milk were identified, and only 6 species were recovered in the bactofuged milk.

It was found that Lysinibacillus fusiformis (80), Macrococcus caseolyticus (22), and Micrococcus aloeverae (22) corresponded to $54 \%$ of the 229 thermoduric isolates from raw and preheated milk. There was also a predominance of endospore-forming bacteria (127/229 or $55 \%$ ) among the isolates, corresponding to the species L. fusiformis, Bacillus licheniformis, Lysinibacillus varians, Bacillus toyonensis and Bacillus invictae.

According to Table 3, the isolates of L. fusiformis, which represented $35 \%$ of the thermoduric bacteria in raw and preheated milk, presented 5 distinct genetic types (clusters I, VIII, XX, XXIV, and XXV), which may have been determined by different sources of contamination for all evaluated batches. This species was isolated as a MT and PT from batches A, B, and C, and as a TT only in the raw milk sample from batch A. Additionally, in relation to the TT recovered from raw milk from batch A, the species B. licheniformis and $B$. invictae were also identified.

For the PT isolates of raw and preheated milk ( $\mathrm{n}=$ 64), L. fusiformis (36\%), M. aloeverae (11\%) and L. varians (9\%) predominated in addition to other species (Table 3). The Gordonia paraffinivorans species was notable as it represented $5 \%$ of the PT, was isolated exclusively as a psychrotrophic microorganism, was an isolate obtained from each batch of milk (A,
$\mathrm{B}$, and $\mathrm{C}$ ), belonged to the same cluster (XXI), and demonstrated an origin common to the 3 batches (e.g., biofilms in a bulk transport vehicle or the water used in the cheese factory). The ability to form biofilms by microorganisms of this genus has been reported previously (Arenskötter, Bröker and Steinbüchel, 2004), and the species was described by Xue et al. (2003) as capable of degrading hydrocarbons. No previous reports were found regarding the isolation of this species in milk.

Table 4 demonstrates that among the microorganisms remaining for bactofugation, L. fusiformis and $B$. licheniformis species predominated $(74 \%)$. Both species are known to be endospore-forming psychrotrophs and have proteolytic or lipolytic activity (De Jonghe et al., 2010; Miller et al., 2015; Pinto et al., 2018; Ribeiro Júnior et al., 2018b).

The bactofugation process was sufficient to reduce $(37.5 \%)$ the isolation of $L$. fusiformis with mesophilic behavior from 80 (raw and preheated milk) to 50 (bactofuged milk), and to remove all microbes that had psychrotrophic and thermophilic metabolism. We also reported that this species has the highest incidence among psychrotrophic residues of bactofugation (Ribeiro Júnior et al., 2019b). Apparently, this greater recovery in bactofuged milk is proportionally linked to the higher incidence of this species in raw milk.

Similarly, bactofugation reduced the counts of $B$. licheniformis, B. toyonensis, M. aloeverae, and Aestuariimicrobium kwangyangense by $33 \%, 43 \%, 86 \%$, and $92 \%$, respectively, in addition to reducing isolates from Macrococcus caseolyticus, L. varians, Carnobacterium divergens, Microbacterium hominis, Kocuria indica, Micrococcus yunnanensis, G. paraffinivorans, B. invictae, and Kocuria kristinae to undetectable levels. These measurements are probably affected by the resistance of each isolate to temperature and other intrinsic characteristics of the microorganisms.

Table 4. Identification by cluster of genetic similarity of mesophilic thermoduric residues of bactofugation from 3 batches of preheated milk

\begin{tabular}{llcc}
\hline 16S rRNA clustering identification & Cluster & $\mathrm{n}$ & Total (\%) \\
\hline Lysinibacillus fusiformis & $\mathrm{X}$ & 48 & $50(61.7)$ \\
& XI & 1 & \\
Bacillus licheniformis & VI & 1 & $10(12.3)$ \\
Microbacterium lacticum & VIII & 7 & $9(11.1)$ \\
Bacillus toyonensis & IX & 3 & $8(9.9)$ \\
& V & 9 & \\
Micrococcus aloeverae & III & 4 & $3(3.7)$ \\
Aestuariimicrobium kwangyangense & IV & 1 & $1(1.2)$ \\
Total & VII & 3 & $81(100)$ \\
\hline
\end{tabular}




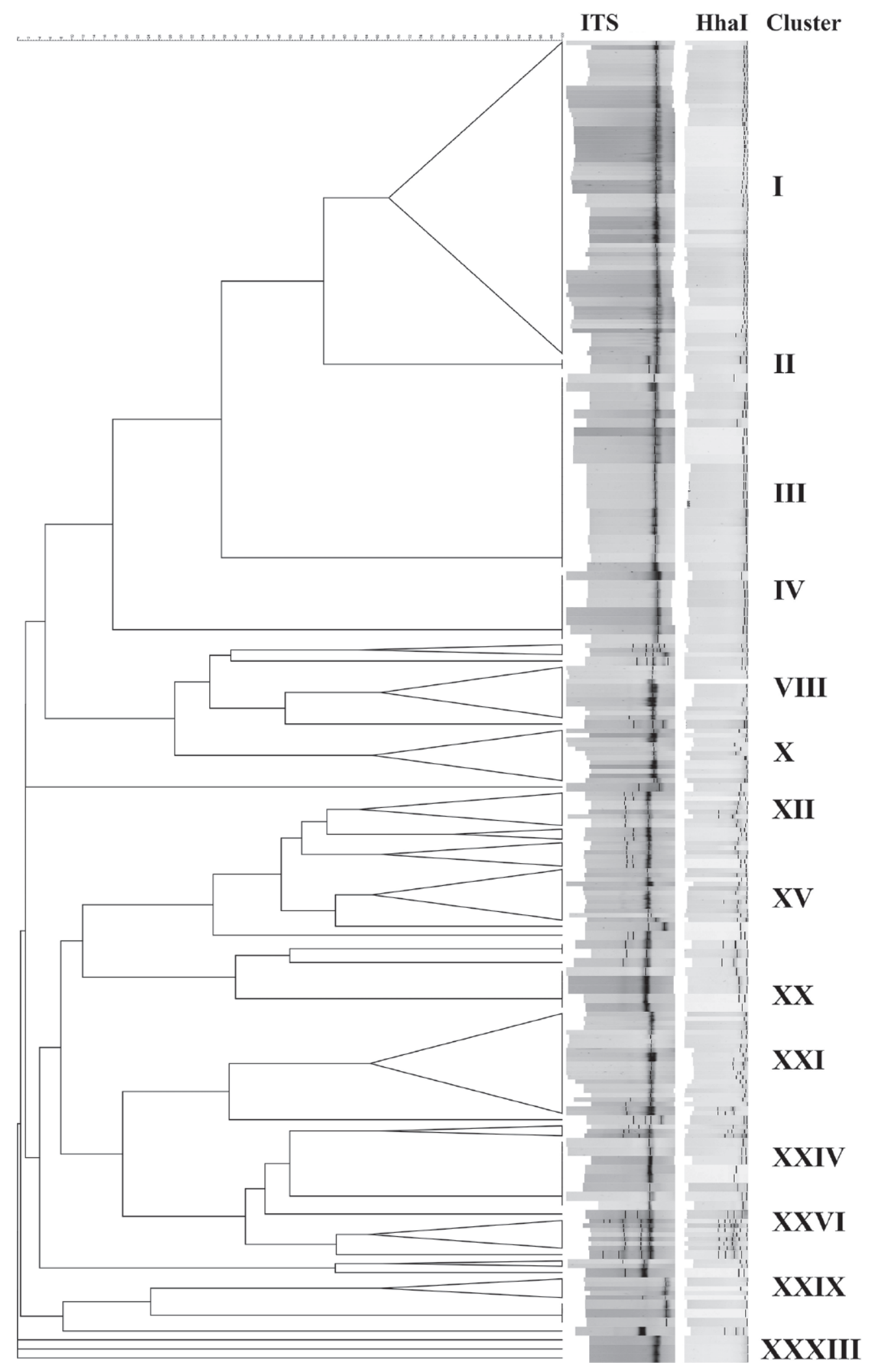

Figure 1. Dendrogram of genetic similarity of thermoduric bacteria isolated from 3 batches of raw and preheated milk before bactofugation, as constructed using the variable internal transcribed spacer (ITS) region amplification profile and the restriction of DNA from respective bacteria samples with the HhaI enzyme. Thirty-three clusters with $60 \%$ genetic similarity were observed; some are represented with numerals (I to XXXIII). 


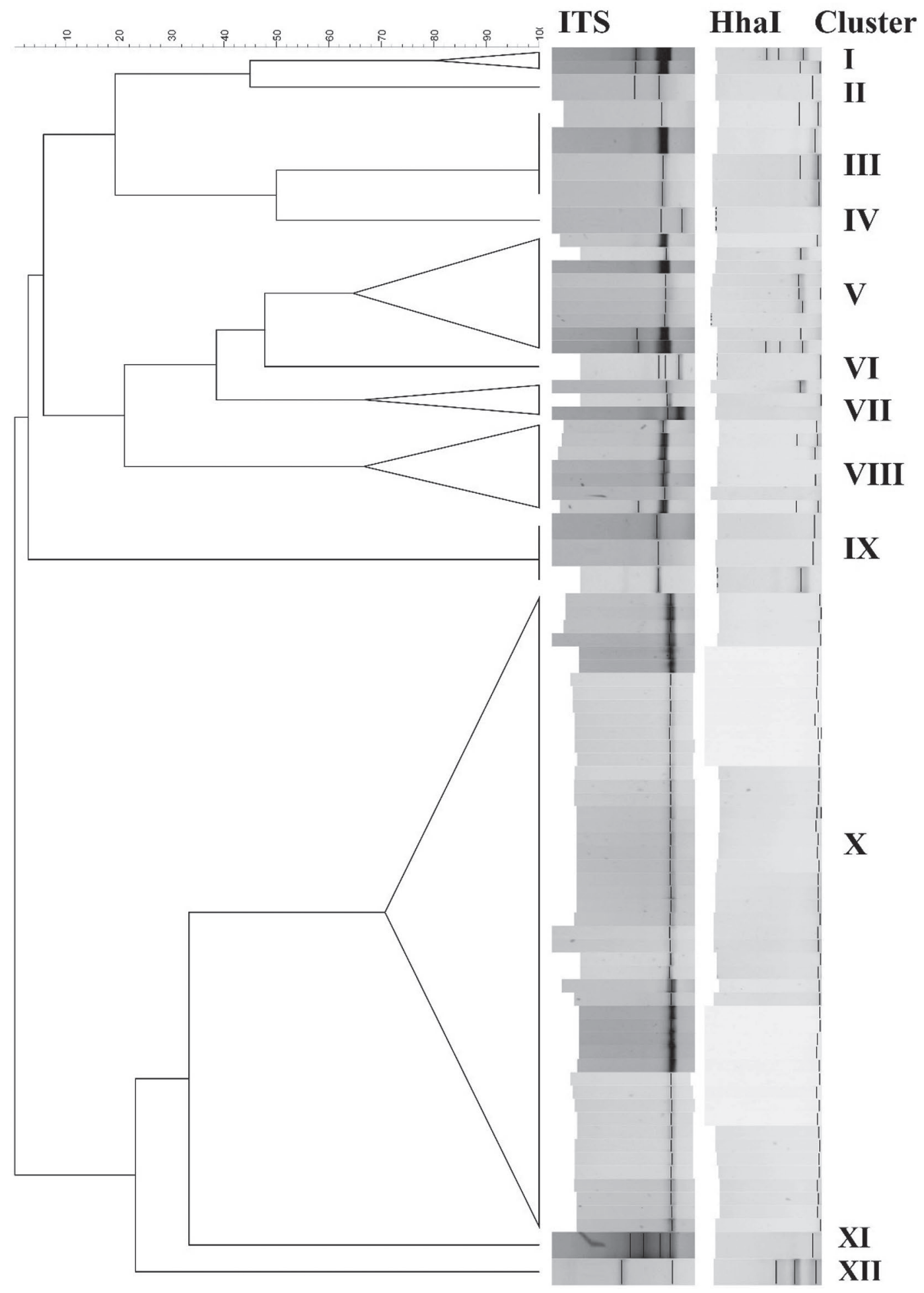

Figure 2. Dendrogram of genetic similarity of thermoduric bacteria isolated from 3 batches of raw and preheated milk after the bactofugation process, constructed using the internal transcribed spacer (ITS) region amplification profile variables and the restriction of DNA from respective bacteria samples with the HhaI enzyme. Twelve clusters can be observed with $60 \%$ genetic similarity, identified here from I to XII. 
We emphasize that in this study we followed the Standard Methods for the Examination of Dairy Products (Frank and Yousef, 2004) for the thermoduric enumeration, which simulates vat pasteurization in analytical and laboratory conditions. Under industrial processing conditions using HTST pasteurization, the composition of the thermoduric microbiota could be changed.

\section{CONCLUSIONS}

The bactofugation of raw milk, preceded by preheating to $55^{\circ} \mathrm{C}$, significantly reduced thermoduric bacteria counts. The MT remaining in the bactofuged milk was similarly reduced in diversity and quantity compared with those observed in the milk before bactofugation. Endospore-forming microorganisms with spoilage potential predominate among the thermoduric residues of bactofugation. Thus, this process can be used to reduce the microorganisms in raw milk resistant to pasteurization, preserving its quality, in association with other techniques that help control the microbiological contamination of raw milk by endospore-forming bacteria.

\section{ACKNOWLEDGMENTS}

This study was supported by the following Brazilian institutes: the National Council of Scientific and Technological Development (CNPq, Brasília, Brazil; grant number 305062/2015-8), the Brazilian Federal Agency for Support and Evaluation of Graduate Education (CAPES, Brasília, Brazil; process 88887.145705/201700), Financing of Studies and Projects (FINEP, Brasília, Brazil), and the Araucaria Foundation (FAP/PR, Curitiba, Paraná, Brazil). The authors are grateful to researcher Elis Lorenzetti (Laboratory of Animal Virology, UEL, Londrina, Paraná, Brazil) for providing assistance in molecular biology. The authors have not stated any conflicts of interest.

\section{REFERENCES}

Arenskötter, M., D. Bröker, and A. Steinbüchel. 2004. Biology of the metabolically diverse genus Gordonia. Appl. Environ. Microbiol. 70:3195-3204. https://doi.org/10.1128/AEM.70.6.3195-3204.2004.

De Jonghe, V., A. Coorevits, J. De Block, E. Van Coillie, K. Grijspeerdt, L. Herman, P. De Vos, and M. Heyndrickx. 2010. Toxinogenic and spoilage potential of aerobic spore-formers isolated from raw milk. Int. J. Food Microbiol. 136:318-325. https://doi.org/10 .1016/j.ijfoodmicro.2009.11.007.

Delgado, S., C. T. Rachid, E. Fernández, T. Rychlik, A. Alegría, R. S. Peixoto, and B. Mayo. 2013. Diversity of thermophilic bacteria in raw, pasteurized and selectively-cultured milk, as assessed by culturing, PCR-DGGE and pyrosequencing. Food Microbiol. 36:103-111. https://doi.org/10.1016/j.fm.2013.04.015.

Dice, L. R. 1945. Measures of the amount of ecologic association between species. Ecology 26:297-302. https://doi.org/10.2307/ 1932409.
Durak, M. Z., H. I. Fromm, J. R. Huck, R. N. Zadoks, and K. J. Boor. 2006. Development of molecular typing methods for Bacillus spp. and Paenibacillus spp. isolated from fluid milk products. J. Food Sci. 71:M50-M56. https://doi.org/10.1111/j.1365-2621.2006 .tb08907.x.

Edwards, U., T. Rogall, H. Blöcker, M. Emde, and E. C. Böttger. 1989. Isolation and direct complete nucleotide determination of entire genes. Characterization of a gene coding for $16 \mathrm{~S}$ ribosomal RNA. Nucleic Acids Res. 17:7843-7853. https://doi.org/10.1093/ nar/17.19.7843.

Faccia, M., M. Mastromatteo, A. Conte, and M. Nobile. 2013. Influence of the milk bactofugation and natural whey culture on the microbiological and physico-chemical characteristics of mozzarella cheese. J. Food Process. Technol. 4:1-7. https://doi.org/10.4172/ 2157-7110.1000218.

Farkye, N. Y. 2004. Cheese technology. Int. J. Dairy Technol. 57:9198. https://doi.org/10.1111/j.1471-0307.2004.00146.x.

Frank, J. F., and A. E. Yousef. 2004. Tests for groups of microorganisms. Pages 281-292 in Standard Methods for the Examination of Dairy Products, 17th ed. H. M. Wehr and J. F. Frank, ed. American Public Health Association, Washington, DC.

Gésan-Guiziou, G. 2010. Removal of bacteria, spores and somatic cells from milk by centrifugation and microfiltration techniques. Pages 349-372 in Improving the Safety and Quality of Milk: Milk Production and Processing. M. W. Griffiths, ed. Woodhead Publishing, Cambridge, UK.

Hall, T. A. 1999. BioEdit: A user-friendly biological sequence alignment editor and analysis program for Windows 95/98/NT. Nucl. Acids Symp. Ser. 41:95-98.

Huang, X., and A. Madan. 1999. CAP3: A DNA sequence assembly program. Genome Res. 9:868-877. https://doi.org/10.1101/gr.9.9 .868 .

Huck, J. R., B. H. Hammond, S. C. Murphy, N. H. Woodcock, and K. J. Boor. 2007. Tracking spore-forming bacterial contaminants in milk fluid milk-processing systems. J. Dairy Sci. 90:4872-4883. https://doi.org/10.3168/jds.2007-0196.

Khanal, S. N., S. Anand, K. Muthukumarappan, and M. Huegli. 2014. Inactivation of thermoduric aerobic sporeformers in milk by ultrasonication. Food Control 37:232-239. https://doi.org/10.1016/ j.foodcont.2013.09.022.

Kosikowski, F. V., and P. F. Fox. 1968. Low heat, hydrogen peroxide and bactofugation treatments of milk to control coliforms in Cheddar cheese. J. Dairy Sci. 51:1018-1022. https://doi.org/10.3168/ jds.S0022-0302(68)87116-4.

Kumar, S., G. Stecher, M. Li, C. Knyaz, and K. Tamura. 2018. MEGA $\mathrm{X}$ : molecular evolutionary genetics analysis across computing platforms. Mol. Biol. Evol. 35:1547-1549. https://doi.org/10.1093/ molbev/msy096.

Mane, V. N., and M. B. Gandhi. 2011. Studies on proteolytic thermoduric psychotrophic bacteria in milk and fermented milk products. J. Environ. Res. Dev. 5:384-392.

Masiello, S. N., D. Kent, N. H. Martin, Y. H. Schukken, M. Wiedmann, and K. J. Boor. 2017. Longitudinal assessment of dairy farm management practices associated with the presence of psychrotolerant Bacillales spores in bulk tank milk on 10 New York State dairy farms. J. Dairy Sci. 100:8783-8795. https://doi.org/10 .3168/jds.2017-13139.

Miller, R. A., D. J. Kent, M. J. Watterson, K. J. Boor, N. H. Martin, and M. Wiedmann. 2015. Spore populations among bulk tank raw milk and dairy powders are significantly different. J. Dairy Sci 98:8492-8504. https://doi.org/10.3168/jds.2015-9943.

Murphy, S. C., N. H. Martin, D. M. Barbano, and M. Wiedmann. 2016. Influence of raw milk quality on processed dairy products: How do raw milk quality test results relate to product quality and yield? J. Dairy Sci. 99:10128-10149. https://doi.org/10.3168/jds .2016-11172.

Normand, P., C. Ponsonnet, X. Nesme, M. Neyra, and P. Simonet. 1996. ITS analysis of prokaryotes. Pages 1-12 in Molecular Microbial Ecology Manual. D. L. Akkermans, J. D. Van Elsas, E. I. 
De Bruijn, ed. Kluwer Academic Publishers, Dordrecht, the Netherlands.

Oliveira, R. B., L. P. Margalho, J. S. Nascimento, L. E. Costa, J. B. Portela, A. G. Cruz, and A. S. Sant'Ana. 2016. Processed cheese contamination by spore-forming bacteria: A review of sources, routes, fate during processing and control. Trends Food Sci. Technol. 57:11-19. https://doi.org/10.1016/j.tifs.2016.09.008.

Osborne, C. A., M. Galic, P. Sangwan, and P. H. Janssen. 2005. PCR generated artefact from $16 \mathrm{~S}$ rRNA gene-specific primers. FEMS Microbiol. Lett. 248:183-187. https://doi.org/10.1016/j.femsle 2005.05.043.

Pinto, C. L., L. V. Souza, V. A. Meloni, C. S. Batista, R. Silva, E. M. Martins, A. G. Cruz, and M. L. Martins. 2018. Microbiological quality of Brazilian UHT milk: Identification and spoilage potential of spore-forming bacteria. Int. J. Dairy Technol. 71:20-26. https://doi.org/10.1111/1471-0307.12339.

Ranjard, L., F. Poly, J. C. Lata, C. Mougel, J. Thioulouse, and S. Nazaret. 2001. Characterization of bacterial and fungal soil communities by automated ribosomal intergenic spacer analysis fingerprints: Biological and methodological variability. Appl. Environ. Microbiol. 67:4479-4487. https://doi.org/10.1128/AEM.67.10 .4479-4487.2001.

Ribeiro Júnior, J. C., A. M. Oliveira, F. G. Silva, L. N. H. Garcia, C. M. O. Lobo, B. Alexandrino, R. Tamanini, and V. Beloti. 2019a. Influence of the microbiological quality of raw milk on the shelf life of pasteurized milk. Semin. Cienc. Agrar. 40:1469-1476. https:// doi.org/10.5433/1679-0359.2019v40n4p1469.

Ribeiro Júnior, J. C., G. A. Peruzi, S. R. Bruzaroski, R. Tamanini, C. M. O. Lobo, B. Alexandrino, A. C. M. Conti, A. A. Alfieri, and V. Beloti. 2019b. Effect of bactofugation of raw milk on counts and microbial diversity of psychrotrophs. J. Dairy Sci. 102:7794-7799. https://doi.org/10.3168/jds.2018-16148.

Ribeiro Júnior, J. C., R. Tamanini, A. L. M. de Oliveira, A. A. Alfieri, and V. Beloti. 2018a. Genetic diversity of thermoduric spoilage microorganisms of milk from Brazilian dairy farms. J. Dairy Sci. 101:6927-6936. https://doi.org/10.3168/jds.2017-13948.

Ribeiro Júnior, J. C., R. Tamanini, A. L. M. de Oliveira, J. Ribeiro, and V. Beloti. 2018b. Spoilage potential of spore-forming bacteria from refrigerated raw milk. Semin. Cienc. Agrar. 39:2049-2058. https://doi.org/10.5433/1679-0359.2018v39n5p2049.

Ribeiro Júnior, J. C., R. Tamanini, B. F. Soares, A. M. de Oliveira, F. G. Silva, F. F. da Silva, N. A. Augusto, and V. Beloti. 2016. Efficiency of boiling and four other methods for genomic DNA extraction of deteriorating spore-forming bacteria from milk. Semin. Cienc. Agrar. 37:3069-3078. https://doi.org/10.5433/1679-0359 .2016v37n5p3069.

Sneath, P. H., and R. R. Sokal. 1973. Numerical Taxonomy: The Principles and Practice of Numerical Classification. W. H. Freeman and Company, San Francisco, CA.

Stack, A., and G. Sillen. 1998. Bactofugation of liquid milks. Nutr. Food Sci. 98:280-282. https://doi.org/10.1108/00346659810224217.

Torres-Anjel, M. J., and T. I. Hedrick. 1971. Spore removal by centrifugation and its effect on ultra-high temperature commercial sterilization of milk. J. Dairy Sci. 54:326-330. https://doi.org/10 .3168/jds.S0022-0302(71)85837-X.

Xue, Y., X. Sun, P. Zhou, R. Liu, F. Liang, and Y. Ma. 2003. Gordonia paraffinivorans sp. nov., a hydrocarbon-degrading actinomycete isolated from an oil-producing well. Int. J. Syst. Evol. Microbiol. 53:1643-1646. https://doi.org/10.1099/ijs.0.02605-0.

\section{ORCIDS}

J. C. Ribeiro-Júnior @ https://orcid.org/0000-0002-3272-4375

R. Tamanini (๑ https://orcid.org/0000-0002-4497-9164

A. A. Alfieri ๑ https://orcid.org/0000-0002-7024-4487 